through routine sequencing of all enteroviruses detected in clinical materials from 2008 to 2015. J Clin Microbiol. 2016;54:2306-14. http://dx.doi.org/10.1128/JCM.00207-16

3. Grard G, Drexler JF, Lekana-Douki S, Caron M, Lukashev A, Nkoghe D, et al. Type 1 wild poliovirus and putative enterovirus 109 in an outbreak of acute flaccid paralysis in Congo, OctoberNovember 2010. Euro Surveill. 2010;15:pii=19723.

4. Richter J, Tryfonos C, Panagiotou C, Nikolaou E, Koliou M, Christodoulou C. Newly emerging $\mathrm{C}$ group enteroviruses may elude diagnosis due to a divergent $5^{\prime}$-UTR. Int J Infect Dis. 2013; 17:e1245-8.

5. Todd A, Taylor S, Huang QS. Identification of enterovirus C105 for the first time in New Zealand. Western Pac Surveill Response J. 2015;6:60-2. http://dx.doi.org/10.5365/wpsar.2014.5.4.003

6. Zhang T, Ren L, Luo M, Li A, Gong C, Chen M, et al. Enterovirus D68-associated severe pneumonia, China, 2014. Emerg Infect Dis. 2015;21:916-8. http://dx.doi.org/10.3201/eid2105.150036

7. Nix WA, Oberste MS, Pallansch MA. Sensitive, seminested PCR amplification of VP1 sequences for direct identification of all enterovirus serotypes from original clinical specimens. J Clin Microbiol. 2006;44:2698-704. http://dx.doi.org/10.1128/JCM.00542-06

8. Oberste MS, Penaranda S, Rogers SL, Henderson E, Nix WA. Comparative evaluation of Taqman real-time PCR and semi-nested VP1 PCR for detection of enteroviruses in clinical specimens. J Clin Virol. 2010;49:73-4.

9. Barnadas C, Midgley SE, Skov MN, Jensen L, Poulsen MW, Fischer TK. An enhanced enterovirus surveillance system allows identification and characterization of rare and emerging respiratory enteroviruses in Denmark, 2015-16. J Clin Virol. 2017;93:40-4.

Address for correspondence: Fang Huang, Beijing Center for Disease Prevention and Control, Institute for Communicable Disease Control and Prevention, No. 16, Hepingli Middle Av, Dongcheng District, Beijing 100013, China; email: hhffxdd@126.com

\section{Recent Findings of Potentially Lethal Salamander Fungus Batrachochytrium salamandrivorans}

\author{
David Lastra González, Vojtech Baláž, \\ Milič Solský, Barbora Thumsová, \\ Krzysztof Kolenda, Anna Najbar, \\ Bartłomiej Najbar, Matej Kautman, Petr Chajma, \\ Monika Balogová, Jiří Vojar
}

Author affiliations: Czech University of Life Sciences, Prague, Czech Republic (D. Lastra González, M. Solský, B. Thumsová, P. Chajma, J. Vojar); University of Veterinary and Pharmaceutical Sciences, Brno, Czech Republic (V. Baláž, M. Kautman); University of Wrocławski, Wroclaw, Poland (K. Kolenda,
A. Najbar); University of Zielona Góra, Lubuskie, Poland

(B. Najbar); Slovak Academy of Sciences, Košice, Slovakia

(M. Kautman); Pavol Jozef Šafárik University in Košice, Košice

(M. Balogová)

DOI: https://doi.org/10.3201/eid2507.181001

The distribution of the chytrid fungus Batrachochytrium salamandrivorans continues to expand in Europe. During 2014-2018, we collected 1,135 samples from salamanders and newts in 6 countries in Europe. We identified 5 cases of $B$. salamandrivorans in a wild population in Spain but none in central Europe or the Balkan Peninsula.

$\mathrm{C}$ hytridiomycosis, an amphibian disease caused by the chytrid fungi Batrachochytrium dendrobatidis and $B$. salamandrivorans, is responsible for declines of amphibian populations worldwide (1). The recently discovered $B$. salamandrivorans (2) is severely impacting salamanders and newts in Europe $(3,4)$. This emerging fungal pathogen infects the skin of caudates and causes lethal lesions (2). It most likely was introduced to Europe by the pet salamander trade from Southeast Asia (3). In Europe, the Netherlands, Belgium, and Germany have confirmed B. salamandrivorans in wild caudates; the United Kingdom, Germany, and Spain have confirmed the fungus in captive animals $(5,6)$. Several countries have established trade regulations (5) and a recent European Union decision, no. 2018/320, implements measures to protect against the spread of $B$. salamandrivorans via traded salamanders (7). The World Organisation for Animal Health listed infection with $B$. salamandrivorans as a notifiable disease in 2017. In addition to controlling the amphibian pet trade, surveillance of the pathogen is urgently needed to establish disease intervention strategies in affected areas and prevention in $B$. salamandrivorans-free regions.

During 2014-2018, we collected 1,135 samples directly for the detection of B. salamandrivorans or as a part of unrelated studies. Samples came from 10 amphibian species at 47 sites in 6 countries in Europe. Most samples came from the fire salamander, Salamandra salamandra, which is a known suitable host for $B$. salamandrivorans (3), and the palmate newt, Lissotriton helveticus, which is known to be resistant to B. salamandrivorans (Appendix Table 1, http://wwwnc. cdc.gov/EID/article/25/7/18-1001-App1.pdf).

Most samples were skin swabs collected by following the standard procedure for sampling of amphibian chytrid fungi (8). A smaller portion of samples was toe clippings (Appendix Table 2). We extracted genomic DNA following the protocol of Blooi et al. (9), and 2 laboratories with different equipment tested for $B$. salamandrivorans. Samples from Spain and the Czech Republic initially were analyzed at the Czech University of Life Sciences (Prague, Czech 
Republic) by standard PCR with $B$. salamandrivoransspecific primers STerF and STerR, as described by Martel et al. (2), with subsequent electrophoresis on the amplified target. We reanalyzed samples that produced positive or equivocal results by using duplex quantitative PCR (qPCR) for B. dendrobatidis and B. salamandrivorans (9) at the University of Veterinary and Pharmaceutical Sciences (Brno, Czech Republic). Trenton Garner of the Institute of Zoology, Zoological Society of London (London, England), provided DNA for quantification standards of the $B$. dendrobatidis GPL lineage, strain IA042, and An Martel of Ghent University (Ghent, Belgium) provided quantification standards of B. salamandrivorans.

We directly analyzed samples from other countries by qPCR. We used negative and positive controls for standard PCR analyses and quantification standards for qPCR analyses. For B. dendrobatidis- or B. salamandrivorans-positive sites, we estimated prevalence and Bayesian $95 \%$ CIs using 3 parallel Markov chains with 2,000 iterations each, a burn-in of 1,000 iterations, and no thinning (Appendix Table 1). We performed all statistical analyses in R 3.3.1 using the R2WinBUGS package and WinBUGS 1.4.3 (10).

Samples from $5 \mathrm{~L}$. helveticus newts tested positive for $B$. salamandrivorans, implying that this species is not resistant to this fungus as previously indicated by experimental exposures (3). The positive cases were found in populations from an isolated area encompassing 2 different regions in northern Spain, Cantabria and Asturias, with remote human populations. Four cases were found in livestock drinking troughs located $150-1,000 \mathrm{~m}$ above sea level, and 1 case was found in a pond in a private garden, $30 \mathrm{~km}$ from the nearest recorded case. We did not find $B$. salamandrivorans-positive cases in consecutive locations during our monitoring.

Although $B$. salamandrivorans cases have been reported in captive salamanders (6), our reported cases were $>1,000 \mathrm{~km}$ from any area of known $B$. salamandrivorans occurrence (7). We also detected $B$. dendrobatidis by duplex qPCR in 11 samples from 3 newt species (L. helveticus, L. vulgaris, and Triturus cristatus) from Spain and Montenegro and 1 captive Cynops ensicauda newt from the Czech Republic. The B. dendrobatidis-positive cases did not involve co-infection with $B$. salamandrivorans.

We confirmed that the known distribution of B. salamandrivorans continues to expand in Europe, indicating that this fungus might be capable of dispersing over long distances (4), might be introduced by humans, or might even have been circulating in this geographic range with no detected deaths. Our results should alert the research and conservation community and motivate urgent action to identify regions with early emergence of the disease and implement mitigation measures to prevent further spread of this deadly pathogen.

\section{Acknowledgments}

We thank the Cantabria delegation of SEO/Birdlife; Fundación Zoo Santillana del Mar; workers from Marismas de Santoña, Victoria y Joyel Natural Park, with special thanks to Carlos Rubio; Pepo Nieto, Pedro Barreda, and his family; Elena Kulikova and Wiesław Babik; and also our friends Daniel Koleška, Kamila Šimůnková, Tomáš Holer, and Daniela Budská for fieldwork.

This work was performed with permission from the Nature Conservation Agency of the Czech Republic; Agency for Nature and Environment Protection of Montenegro permit no. 02 Broj UPI-321/4; Ministry of Environment of the Slovak Republic, permit no. 4924/2017-6.3; the Endangered Species Section of Environmental Service of Cantabria, Spain, permit no. EST419/2017-SEP; the Environmental Service of Castilla y León, Spain, permit no. EP/LE/233/2017; Department of Nature Conservation of Poland, permit nos. DZP-WG.6401.02.7.2014. JRO, WPN.6401.211.2015.MR.2, 78/2014, and 68/2015; the Ministry of Protection of Environment of Croatia, permit no. UP/I-612-07/169-48/68; and agreements from other agencies, including Red Cambera, special thanks to Sergio Tejón and Tomás González; Fondo para la Protección de los Animales Salvajes; and Fundación Naturaleza y Hombre, Spain. The study was supported by the Czech University of Life Sciences, Prague, Czech Republic (grant nos. 20174218 and 20184247) and the Internal Grant Agency of the University of Veterinary and Pharmaceutical Sciences, Brno, Czech Republic (grant no. 224/2016/FVHE). K.K. was supported by MNiSW grant for Young Scientists no. 0420/1408/16; A.N. was supported by grant no. DS 1076/S/ IBŚ/2014 and MNiSW grant for Young Scientists no. 0420/1409/16.

\section{About the Author}

Mr. Lastra González is a PhD candidate at Czech University of Life Sciences, Prague. His research focuses on amphibian conservation and emerging infectious diseases that affect them.

\section{References}

1. Berger L, Roberts AA, Voyles J, Longcore JE, Murray KA, Skerratt LF. History and recent progress on chytridiomycosis in amphibians. Fungal Ecol. 2016;19:89-99. http://dx.doi.org/ 10.1016/j.funeco.2015.09.007

2. Martel A, Spitzen-van der Sluijs A, Blooi M, Bert W, Ducatelle R, Fisher MC, et al. Batrachochytrium salamandrivorans sp. nov. causes lethal chytridiomycosis in amphibians. Proc Natl Acad Sci U S A. 2013;110:15325-9. http://dx.doi.org/10.1073/ pnas. 1307356110

3. Martel A, Blooi M, Adriaensen C, Van Rooij P, Beukema W, Fisher MC, et al. Recent introduction of a chytrid fungus endangers Western Palearctic salamanders. Science. 2014;346:630-1. http://dx.doi.org/10.1126/science. 1258268

4. Stegen G, Pasmans F, Schmidt BR, Rouffaer LO, Van Praet S, Schaub M, et al. Drivers of salamander extirpation mediated by Batrachochytrium salamandrivorans. Nature. 2017;544:353-6. http://dx.doi.org/10.1038/nature22059 
5. European Food Safety Authority Panel on Animal Health and Welfare, More S, Angel Miranda M, Bicout D, Bøtner A, Butterworth A, et al. Risk of survival, establishment and spread of Batrachochytrium salamandrivorans ( $\mathrm{Bsal}$ ) in the EU. EFSA Journal. 2018;16:5259. http://dx.doi.org/10.2903/j.efsa.2018.5259

6. Fitzpatrick LD, Pasmans F, Martel A, Cunningham AA. Epidemiological tracing of Batrachochytrium salamandrivorans identifies widespread infection and associated mortalities in private amphibian collections. Sci Rep. 2018;8:13845. http://dx.doi.org/ 10.1038/s41598-018-31800-z

7. Commission Implementing Decision (EU) 2018/320 of 28 February 2018 on certain animal health protection measures for intra-Union trade in salamanders and the introduction into the Union of such animals in relation to the fungus Batrachochytrium salamandrivorans. Official Journal of the European Union. 2018;L62:18-33 [cited 2018 Jun 1]. http://data.europa.eu/eli/ dec_impl/2018/320/oj

8. Hyatt AD, Boyle DG, Olsen V, Boyle DB, Berger L, Obendorf D, et al. Diagnostic assays and sampling protocols for the detection of Batrachochytrium dendrobatidis. Dis Aquat Organ. 2007;73:17592. http://dx.doi.org/10.3354/dao073175

9. Blooi M, Pasmans F, Longcore JE, Spitzen-van der Sluijs A, Vercammen F, Martel A. Duplex real-time PCR for rapid simultaneous detection of Batrachochytrium dendrobatidis and Batrachochytrium salamandrivorans in amphibian samples. J Clin Microbiol. 2013;51:4173-7. http://dx.doi.org/10.1128/JCM.02313-13

10. Lunn DJ, Thomas A, Best N, Spiegelhalter D. WinBUGSa Bayesian modelling framework: concepts, structure, and extensibility. Stat Comput. 2000;10:325-37. http://dx.doi.org/ 10.1023/A:1008929526011

Address for correspondence: David Lastra González, Faculty of Environmental Sciences, Czech University of Life Sciences, Kamýcká 129, 16521 Prague-Suchdol, Czech Republic; email: lastra_gonzalez@fzp.czu.cz

\section{Crimean-Congo Hemorrhagic Fever Virus Genome in Tick from Migratory Bird, Italy}

\author{
Elisa Mancuso, Luciano Toma, Andrea Polci, \\ Silvio G. d'Alessio, Marco Di Luca, \\ Massimiliano Orsini, Marco Di Domenico, \\ Maurilia Marcacci, Giuseppe Mancini, \\ Fernando Spina, Maria Goffredo, \\ Federica Monaco
}

Author affiliations: Istituto Zooprofilattico Sperimentale dell'Abruzzo e del Molise "G. Caporale," Teramo, Italy (E. Mancuso, A. Polci, S.G. d'Alessio, M. Orsini, M. Di Domenico, M. Marcacci, G. Mancini, M. Goffredo,
F. Monaco); Istituto Superiore di Sanità, Rome, Italy (L. Toma, M. Di Luca); Istituto Superiore per la Protezione e la Ricerca Ambientale, Bologna, Italy (F. Spina)

DOI: https://doi.org/10.3201/eid2507.181345

We detected Crimean-Congo hemorrhagic fever virus in a Hyalomma rufipes nymph collected from a whinchat (Saxicola rubetra) on the island of Ventotene in April 2017. Partial genome sequences suggest the virus originated in Africa. Detection of the genome of this virus in Italy confirms its potential dispersion through migratory birds.

$\mathrm{C}$ rimean-Congo hemorrhagic fever virus (CCHFV) is a vectorborne virus responsible for severe illness in humans, whereas other mammals usually act as asymptomatic reservoirs. The virus is transmitted through tick bites or by direct contact with blood or body fluids of infected vertebrate hosts. CCHFV, an Orthonairovirus within the Nairoviridae family, has a negative-sense tripartite RNA genome characterized by high genetic diversity. The sequences of the circulating strains cluster in 6 genotypes (I-VI) reflecting their geographic origin; worldwide distribution is the result of efficient dispersion through migratory birds, human travelers, and the trade and movement of livestock and wildlife $(1,2)$. In Europe, CCHFV distribution was limited to the Balkan region until 2010, when the virus was identified in ticks collected from a red deer (Cervus elaphus) and, 6 years later, in 2 autochthonous human cases in the same region of Spain (3). Sequences from the Iberia strains clustered in the Africa genotype III (4), supporting the hypothesis of CCHFV dispersion through ticks hosted by migrating birds.

The role of birds in the potential spread of the virus was confirmed by CCHFV detection in ticks collected from migratory birds in Greece in 2009 (5) and Morocco in 2011 (6). Because Italy hosts an intense passage of birds migrating along major routes connecting winter quarters in Africa and breeding areas in Europe, the country is potentially exposed to the risk for virus introduction. We report the detection of CCHFV RNA in a tick collected in Italy from a migratory bird.

We conducted tick sampling during March-May 2017 on the island of Ventotene, where a ringing station has been operating since 1988 as part of the Small Islands Project, a large-scale and long-term effort to monitor spring migrations of birds across the central and western Mediterranean. We ringed 5,095 birds and checked $\approx 80 \%$ for ectoparasites. We collected 14 adults, 330 nymphs, and 276 larvae from 268 passerines belonging to 28 species; 18 species were trans-Saharan migrants. We stored ticks in $70 \%$ ethanol until morphologic identification and assignment to a genus or, whenever possible, a species (7). We then individually 